\title{
ANTAGONISM OF SAXITOXIN AND TETRODOTOXIN BLOCK BY INTERNAL MONOVALENT CATIONS IN SQUID AXON
}

Gerry S. Oxford ${ }^{1}$, Paul Forscher ${ }^{2}$, P. Kay Wagoner ${ }^{3}$, and David J. Adams, ${ }^{4 * *}$

The Marine Biological Laboratory, Woods Hole, MA 02543 USA

*Address correspondence to: David J. Adams, Illawarra Health \& Medical Research Institute (IHMRI), University of Wollongong, Wollongong, NSW 2522 Australia

ORCID iD: 0002-7030-2288; Email: djadams@uow.edu.au

Present addresses:

${ }^{1}$ Department of Pharmacology and Toxicology, Indiana University School of Medicine, Indianapolis, IN 46202 USA.

${ }^{2}$ Department of Molecular, Cellular, and Developmental Biology, Yale University, New Haven, CT 06520 USA.

${ }^{3}$ Department of Cell Biology and Physiology, University of North Carolina School of Medicine, Chapel Hill, NC 27599 USA.

${ }^{4}$ Illawarra Health and Medical Research Institute (IHMRI), University of Wollongong, Wollongong, NSW 2522 Australia. 


\begin{abstract}
The block of voltage-dependent sodium channels by saxitoxin (STX) and tetrodotoxin (TTX) was investigated in voltage-clamped squid giant axons internally perfused with a variety of permeant monovalent cations. Substitution of internal $\mathrm{Na}^{+}$by either $\mathrm{NH}_{4}^{+}$or $\mathrm{N}_{2} \mathrm{H}_{5}{ }^{+}$resulted in a reduction of outward current through sodium channels under control conditions. In contrast, anomalous increases in both inward and outward currents were seen for the same ions if some of the channels were blocked by STX or TTX, suggesting a relief of block by these internal cations. External $\mathrm{NH}_{4}{ }^{+}$was without effect on the apparent magnitude of toxin block. Likewise, internal inorganic monovalent cations were without effect, suggesting that proton donation by $\mathrm{NH}_{4}^{+}$might be involved in reducing toxin block. Consistent with this hypothesis, decreases in internal $\mathrm{pH}$ mimicked internal perfusion with $\mathrm{NH}_{4}{ }^{+}$in reducing toxin block. The interaction between internally applied protons and externally applied toxin molecules appears to be competitive, as transient increases in sodium channel current were observed during step increases in intracellular $\mathrm{pH}$ in the presence of a fixed STX concentration. In addition to these effects on toxin block, low internal $\mathrm{pH}$ produced a voltagedependent block of sodium channels and enhanced steady-state inactivation. Elevation of external buffer capacity only marginally diminished the modulation of STX block by internal $\mathrm{NH}_{4}{ }^{+}$, suggesting that alkalinization of the periaxonal space and a resultant decrease in the cationic STX concentration during $\mathrm{NH}_{4}{ }^{+}$perfusion may play only a minor role in the effect. These observations indicate that internal monovalent cations can exert trans-channel influences on external toxin binding sites on sodium channels.
\end{abstract}




\section{INTRODUCTION}

The movement of sodium ions through voltage-dependent sodium (Nav) channels during excitation of nerve and muscle is selectively and reversibly inhibited by tetrodotoxin (TTX) and saxitoxin (STX). These compounds have proven crucial to our understanding of the behaviour of both $\mathrm{Na}$ and $\mathrm{K}$ channels, to determinations of the surface density of $\mathrm{Nav}$ channels, and are employed in the biochemical isolation, characterization, and functional reconstitution of Nav channels (for reviews see Narahashi, 1974; Catterall, 1992, 1995). Equilibrium and kinetic studies of toxin-receptor for interaction indicate that one toxin molecule blocks one Nav channel (Hille, 1968; Cuervo and Adelman, 1970; Keynes et al., 1971; Colquhoun and Ritchie, 1972). Although it has been proposed that positively charged guanidinium groups on the toxin molecules enter and bind to a site within the channel lumen to block ion flow (Kao and Nishiyama, 1965; Hille, 1975), recent evidence suggests that these toxins bind to a receptor on the external surface of the channel close to, but not in, the permeation pathway (Kao and Walker, 1982; Strichartz, 1984).

Toxin block has been reported to be independent of the species of external cation (Moore et al., 1967) or the direction of current flow (Rojas and Atwater, 1967), yet the binding of radiolabelled TTX and STX is competed by monovalent cations which permeate open channels (Henderson et al., 1974; Barchi and Weigele, 1979; Strichartz et al., 1986). In addition, TTX and STX binding is influenced by extracellular pH (Colquhoun et al., 1972; Henderson and Wang, 1972), external divalent cations (Hille et al., 1975; Strichartz et al., 1986), and solvent properties (Hahin and Strichartz, 1981). Using electrophysiological methods, Ulbricht and Wagner (1975) confirmed that protons compete with TTX for the same site and that occupation of the site either by protons or by toxin would block the Nav channel. In contrast, the influence of divalent cations on toxin effectiveness has been attributed to surface potential induced changes in effective toxin concentration rather than ion-toxin competition (Hille et al., 1975; Grissmer, 1984; but see Strichartz et al., 1986).

The present investigation stems from an observation made during previous experiments on K channel properties (Oxford and Adams, 1981) that very small outward transient currents would consistently appear in voltage-clamped squid axons bathed in TTX when the internal $\mathrm{K}^{+}$ions were substituted by $\mathrm{NH}_{4}{ }^{+}$ions as charge carriers. The kinetics of these transient currents were reminiscent of Nav channels and they could be reduced by conditioning depolarizations. We thus sought to define more clearly the interactions between permeating cations and the toxin binding site and to investigate the possibility that outward ion 
movement could modulate the binding of toxin applied to the external surface. A preliminary report of these results has been published (Oxford, Forscher and Adams, 1984).

\section{MATERIALS AND METHODS}

Experiments were performed on internally perfused giant axons isolated from Loligo pealei at the Marine Biological Laboratory, Woods Hole, MA. The axons were voltage-clamped using conventional axial electrode techniques. Details of the electronics, perfusion, and associated procedures for voltage clamping have been published (Oxford et al., 1978; Oxford, 1981). Ionic currents were low pass filtered (Bessel) at $30 \mathrm{kHz}$ and recorded via a 12 -bit $\mathrm{A} / \mathrm{D}$ convertor interfaced to a PDP 11/23 computer for data storage and analysis. Capacitative and linear leakage currents were digitally subtracted from the records using a "-P/4" averaging procedure. The holding potential was maintained at $-80 \mathrm{mV}$ in all experiments and compensation for series resistance was employed as detailed previously (Oxford, 1981).

The compositions of experimental solutions are given by the following notation: EXTERNAL // INTERNAL, and are detailed in Table I. Variations of the internal $\mathrm{Na}^{+}$ concentration were achieved by equimolar substitution of $\mathrm{Cs}^{+}$(see Oxford and Yeh, 1985). Ionic current contributions through voltage-dependent $\mathrm{K}$ channels were reduced by internal 1 mM 3,4-diaminopyridine (DAP) (Kirsch and Narahashi, 1978). All experiments were done at a temperature of $10 \pm 0.5^{\circ} \mathrm{C}$ controlled by a Peltier cooling device and feedback circuitry.

Internal and external perfusion rates were $50-100 \mu \mathrm{L}, / \mathrm{min}$. and $0.3 \mathrm{ml} / \mathrm{min}$., respectively. Given the volumes of the chamber and axons, this corresponds to solution exchange times of 0.4 and $20 \mathrm{sec}$ for the intracellular and extracellular compartments, respectively.

The concentrations of saxitoxin (STX) and tetrodotoxin (TTX) used in these experiments are overestimates as no correction was made for the degradation of toxin stocks. Chemical reagents used were of analytical grade and 3,4-diaminopyridine was obtained from Aldrich Chemical Co. (Milwaukee, WI).

\section{RESULTS}

\section{Outward ammonium currents are anomalously large at low STX doses}

Under normal intracellular ionic conditions, potassium ions carry most of the outward current through Nav channels, thus we first sought to examine STX block of outward $\mathrm{K}^{+}$currents. In Figure 1 outward $\mathrm{K}^{+}$current families are shown for an axon bathed in $450 \mathrm{mM}$ TMA, $5 \mathrm{mM}$ 
HEPES// and internally perfused with $300 \mathrm{mM} \mathrm{K}^{+}$and $1 \mathrm{mM}$ DAP under control conditions (Fig. 1A) and after the addition of $10 \mathrm{nM} \mathrm{STX}$ to the external solution (Fig. 1B). Transient $\mathrm{K}^{+}$ currents through Nav channels were reduced $74 \%$ by STX. The axon was then returned to STX-free 450 TMA, $5 \mathrm{HEPES} / /$ and internally perfused with $300 \mathrm{mM} \mathrm{NH}_{4}^{+}$. Following recovery of the transient outward currents, now carried by $\mathrm{NH}_{4}^{+}$(Fig. 1C), 10 nM STX was again introduced in the external medium, but in this case, it reduced the transient current by only $12 \%$ (Fig. 1D). This suggests that $\mathrm{NH}_{4}{ }^{+}$currents through Nav channels interfere with the action of STX.

We sought to compare the efficacy of STX block of Nav channels for various permeant cations. In order to assess toxin block for ionic currents of comparable magnitude, we first established the current-carrying capacity of different ions through Nav channels. The magnitudes of outward ionic currents at $+100 \mathrm{mV}$ are illustrated in Figure 2 (solid bars) for various internal monovalent cations and concentrations normalized to values in $300 \mathrm{mM} \mathrm{Na}^{+}$. The magnitude of outward current increases non-linearly for increases in $\mathrm{Na}^{+}$concentration (Hille, 1975). Since comparable currents were obtained for $\left[\mathrm{Na}^{+}\right]$near $100 \mathrm{mM}$ and $\left[\mathrm{NH}_{4}{ }^{+}\right]$at $300 \mathrm{mM}$, we compared STX block in these two cases. In Figure 3, current families from one axon bathed in 450 TMA, 5 HEPES and internally perfused alternately with $/ / 100 \mathrm{Na}^{+}$and //300 $\mathrm{NH}_{4}{ }^{+}$are compared under control conditions (Fig. 3A,B) and following addition of 20 nM STX (Fig. 3C,D). It is clear that $20 \mathrm{nM}$ STX produces much more block of outward $\mathrm{Na}^{+}$ currents (Fig. 3C) than of outward $\mathrm{NH}_{4}{ }^{+}$currents (Fig. 3D).

Evaluation of outward ionic currents for the various monovalent cations in the presence of $20 \mathrm{nM}$ STX (Fig. 2, open bars) reveals that of the ions tested, only ammonium and hydrazinium ions produced anomalously large currents when compared to currents in the absence of toxin. Thus, these ions apparently weaken the block of sodium channels by STX at this concentration. Further experiments exploring this phenomenon were addressed with $\mathrm{NH}_{4}{ }^{+}$ions as the axons were more stable when perfused with ammonium solutions than with hydrazinium solutions.

\section{External $\mathrm{NH}_{4}^{+}$does not reduce STX block of Nav channels}

Ammonium ions can carry current through Nav channels in either direction (Binstock and Lecar, 1969). We thus examined whether the interaction of $\mathrm{NH}_{4}{ }^{+}$ions with $\mathrm{Nav}$ channels during inward currents also resulted in an apparent reduction of toxin block. The degree of toxin block was represented as the ratio of ionic currents in STX vs. control and is plotted as a function of membrane potential in Figure 4A for two axons bathed in $450 \mathrm{Na}^{+} / /$(closed 
symbols) and then $450 \mathrm{NH}_{4}^{+} / /$(open symbols). Substitution of external $\mathrm{NH}_{4}{ }^{+}$for $\mathrm{Na}^{+}$did not alter the degree of block by STX for inward currents at potentials more negative than the reversal potential (measured as $+33 \mathrm{mV}$ in both cells, see legend). In addition, outward currents carried by $\mathrm{Na}^{+}$ions for both cases were also equally sensitive to STX. Thus unlike the case for internal $\mathrm{NH}_{4}^{+}$(Fig. 4B, see below), neither the presence of extracellular $\mathrm{NH}_{4}^{+}$, nor its inward movement through the channel, altered the action of STX on Nav channel currents in either direction.

\section{Internal $\mathrm{NH}_{4}^{+}$inhibits $\mathrm{STX}$ block of inward $\mathrm{Na}^{+}$currents}

To test the effect of internal $\mathrm{NH}_{4}{ }^{+}$on inward $\mathrm{Na}^{+}$currents in the presence and absence of 20 nM STX, $300 \mathrm{NH}_{4}^{+}$was exchanged for $120 \mathrm{Na}^{+}$in the internal perfusate (Fig. 5). Although inward currents in //120 Na and //300 $\mathrm{NH}_{4}^{+}$measured in the absence of toxin were identical as were the reversal potentials, inward $\mathrm{Na}^{+}$currents during STX exposure increase when $\mathrm{NH}_{4}{ }^{+}$(Fig. 5B) replaces $\mathrm{Na}^{+}$(Fig. 5A) internally. These observations on 2 axons are summarized in Figure 4B for a range of membrane potentials during internal perfusion with $/ / 120 \mathrm{Na}^{+}$(closed symbols) and then $/ / 300 \mathrm{NH}_{4}{ }^{+}$(open symbols). It thus appears that inhibition of toxin block by internal $\mathrm{NH}_{4}{ }^{+}$is not limited to ion movement in the outward direction, and that occupancy of an open Nav channel by $\mathrm{NH}_{4}{ }^{+}$may not be required for the effect on STX block.

\section{Ammonium ions inhibit TTX block of Nav channels}

While STX and TTX exhibit identical actions on Nav channels, they are chemically different molecules in terms of structure, valence, and pKa. TTX is monovalent at physiological $\mathrm{pH}$ $\left(\mathrm{pK}_{\mathrm{a}}=8.8\right)$, whereas STX is divalent $\left(\mathrm{pK}_{\mathrm{a}} \mathrm{s}=8.25\right.$ and 11.6). Such differences might be reflected in different sensitivities of their block to inhibition by ammonium ions. To examine this question, we determined the degree of block by TTX in axons perfused with $100 \mathrm{Na}^{+}$as compared to $300 \mathrm{NH}_{4}{ }^{+}$. Internal $\mathrm{NH}_{4}{ }^{+}$ions reduced TTX block of Nav channel currents as they did for STX block. An example of this effect is illustrated in Figure 6, where comparisons of outward $\mathrm{Na}^{+}$and $\mathrm{NH}_{4}{ }^{+}$currents at $+100 \mathrm{mV}$ are made in the absence (Fig. 6A) and presence (Fig. 6B) of $10 \mathrm{nM}$ TTX. While the peak current amplitudes are identical without toxin, in the presence of toxin $\mathrm{NH}_{4}{ }^{+}$currents are approximately twice as large as $\mathrm{Na}^{+}$ currents. 


\section{Internal protons inhibit Nav channel block by external STX and TTX}

A common feature that distinguishes ammonium and hydrazinium ions from the other monovalent cations tested, is their ability to act as proton donors in aqueous solution. In view of the effectiveness of these cations in modulating STX block and of previous evidence that protons compete with STX and TTX for their receptor sites (Ulbricht and Wagner, 1975), we considered the possibility that proton donation by $\mathrm{NH}_{4}{ }^{+}$and $\mathrm{N}_{2} \mathrm{H}_{5}{ }^{+}$might be involved in inhibition of toxin action. To examine this point, we compared STX block of Nav channels as a function of intracellular $\mathrm{pH}$. In the absence of toxin, we examined the effects of lowering intracellular $\mathrm{pH}$ on Nav channel currents. Our experiments lead to three basic observations illustrated by the records in Figure 7. First, in agreement with previous reports (Carbone et al., 1981), we observed a reduction in $\mathrm{Na}^{+}$current as the $\mathrm{pH}$ was lowered from 7.3 to 5.6. This reduction was voltage-dependent as shown for low external $\mathrm{pH}$ (Woodhull, 1973; Begenisich and Danko, 1983) such that proton block was relieved for increasingly positive membrane potentials (Fig. 7A,C). Estimates of the effective electrical location (Woodhull, 1973) of the blocking site within the pore made from peak currents at potentials more positive than $0 \mathrm{mV}$ yielded a value of $0.41 \pm 0.07(\mathrm{n}=3$, S.D.) from the external membrane surface. A second observation was that the steady-state inactivation of Nav channels was more complete at $\mathrm{pH} 5.6$ than at $\mathrm{pH}$ 7.3. This is in agreement with earlier reports (Brodwick and Eaton, 1978; Carbone et al., 1981). A third observation was that the block of Nav channels by internal protons could be partially relieved by increases in the buffer strength in the extracellular solution at a constant $\mathrm{pH}$ of 7.8. Raising the external concentration of HEPES from 5 to $25 \mathrm{mM}$, while maintaining the internal $\mathrm{pH}$ at 5.6 , increased $\mathrm{Na}^{+}$currents at all potentials (compare Fig. 7B to $\mathrm{A}$ and $\mathrm{C}$ ). When the internal $\mathrm{pH}$ was returned to 7.3, changes in external buffer strength had no effect on $\mathrm{Na}^{+}$current magnitude (Fig. 7D,E,F). This result is consistent with the suggestion that protons can pass through open sodium channels (Mozhayeva and Naumov, 1983) and that alterations in buffer strength may modulate a "proton gradient" within the Nav channel pore and effectively regulate the concentration of protons at blocking sites. These observations thus confirm that protons can block sodium channels at sites within the electric field when elevated on the intracellular side.

We then compared the block of sodium channels by external $20 \mathrm{nM}$ STX at internal $\mathrm{pH}$ values of 7.3 and 5.6. Equilibrium block as a function of membrane potential is illustrated in Figure 8 for 3 axons in the two $\mathrm{pH}$ conditions. Two observations can be made regarding these 
results. First, the effectiveness of STX on sodium channels is reduced by internal protons. The relative ionic current $(\mathrm{STX} / \mathrm{Control})$ at potentials above the reversal potential $(+38 \mathrm{mV})$ is $0.29 \pm 0.03$ at $\mathrm{pH} 7.3$, but increases to $0.46 \pm 0.04$ at $\mathrm{pH}$ 5.6. Second, the influence of internal protons on toxin block is progressively weaker for potentials more negative than the reversal potential. That is, the effect of protons on toxin block exhibits a voltage-dependence as does proton block alone.

\section{Internal protons and external toxin molecules interact in a competitive manner}

Measurements of the kinetics of proton and toxin interaction with the sodium channel provide further support for an intimate relationship between their respective binding sites. In the absence of toxin, axons alternately perfused with solutions of $\mathrm{pH} 7.3$ and 5.6 demonstrated monotonic increases and decreases in sodium current, respectively. The time constants for these changes in 2 axons were estimated to be $24 \pm 8$ seconds. As protonation/deprotonation reactions are rapid, this time probably reflects the solution switching time and associated dead space of the perfusion apparatus.

A different result was observed when the internal $\mathrm{pH}$ was switched during exposure to external toxin. Upon return from $\mathrm{pH} 5.6$ to $\mathrm{pH}$ 7.3, the sodium current exhibited a transient increase. This phenomenon is illustrated in Figure 9 for an axon exposed to $20 \mathrm{nM}$ STX. Current magnitudes at $0 \mathrm{mV}$ were obtained at various time points before and after the switch of internal solutions from $\mathrm{pH} 5.6$ to 7.3, and families of currents obtained at the times indicated by the letters. Sodium current increased rapidly as $\mathrm{pH} 7.3$ solution entered the axon but then declined over several minutes to half of the maximum value. Examination of the current family records reveals two major additional points. First, as indicated previously following the switch to $\mathrm{pH} 7.3$, sodium channel inactivation became less complete both at maximum current (b) and after several minutes of perfusion (c). Second, although the outward $\mathrm{Na}^{+}$currents are of comparable magnitude in $\mathrm{pH} 5.6$ (a) and following equilibration in $\mathrm{pH} 7.3$ (c), the inward currents are smaller in $\mathrm{pH}$ 5.6. These observations suggest that the reduced currents in (a) ( $\mathrm{pH}$ 5.6) reflect predominantly proton block which alters inactivation and is voltage-dependent, whereas the reduced currents in (c) reflect block by STX. The transient increase between the two measurements is expected if internal protons and external toxin compete for a common site (Ulbricht, 1981). As illustrated for 4 axons in Figure 10, such transients were seen in several experiments under similar conditions.

The simplest interpretation of these transients is that protons and toxin molecules compete for a binding site, the occupation of which blocks current flow through the channel. 
At an internal $\mathrm{pH}$ of 5.6, the equilibrium for the competitive reaction is shifted towards protonation. When the internal $\mathrm{pH}$ is raised to 7.3 , deprotonation rapidly occurs yielding unblocked channels (free toxin binding sites) and increases in current. Thereafter, a gradual reduction in current occurs due to the slower association of toxin with the channels. The magnitude of the transients reflects the ratio of the dissociation rate constants for protons and STX (Ulbricht, 1981).

\section{Is $\mathrm{NH}_{4}^{+}$relief of toxin block related to periaxonal alkalinization?}

The similarities seen for sodium channel modulation by internal $\mathrm{NH}_{4}{ }^{+}, \mathrm{N}_{2} \mathrm{H}_{5}{ }^{+}$, and $\mathrm{H}^{+}$ions supports the notion that proton donation by $\mathrm{NH}_{4}{ }^{+}$and $\mathrm{N}_{2} \mathrm{H}_{5}{ }^{+}$is involved in the antagonism of STX block. Such reactions by these cations could, however, lead to decreased STX block by a mechanism other than direct competition for a toxin binding site. External $\mathrm{NH}_{4} \mathrm{Cl}$ solutions have been extensively employed as a non-invasive means to elevate intracellular $\mathrm{pH}$ (Roos and Boron, 1981). In such cases, external $\mathrm{NH}_{4}{ }^{+}$ions give up protons to the solution, the resultant $\mathrm{NH}_{3}$ molecules can diffuse into the cell, and there regain protons resulting in alkalinization of the intracellular compartment.

In the present experiments, it is conceivable that during axon perfusion with $300 \mathrm{mM}$ $\mathrm{NH}_{4}{ }^{+}$, sufficient $\mathrm{NH}_{3}$ escapes to and accumulates in the periaxonal space beneath the Schwann cell layer resulting in an elevation of local extracellular $\mathrm{pH}$. A sufficient alkalinization could result in deprotonation of the critical 7,8,9-guanidinium moiety (pKa 8.25, Kao et al., 1983) on some STX molecules, thus reducing the effective active toxin concentration. Clearly, a reduction in toxin concentration would yield less block during perfusion with internal $\mathrm{NH}_{4}^{+}$.

As a test of this possibility, we determined the effect of $\mathrm{NH}_{4}^{+}$perfusion on STX block in axons bathed in solutions ( $\mathrm{pH} 7.8$ ) with elevated extracellular buffer concentrations. In our first experiments, we substituted 450 TMA with 450 Tris. In the 7 axons examined in 450 Tris, we never observed a relief of toxin block with internal $\mathrm{NH}_{4}^{+}$perfusion as seen routinely with 450 TMA. This result is consistent with the idea that Tris can buffer against periaxonal alkalinization which would otherwise reduce the active STX concentration. In contrast, in 3 axons, raising the concentration of HEPES buffer in 450 TMA from $5 \mathrm{mM}$ to either 25 or 50 $\mathrm{mM}$ did not attenuate the relief of STX block by internal $\mathrm{NH}_{4}{ }^{+}$perfusion. The relative effectiveness of $450 \mathrm{mM}$ external Tris to $50 \mathrm{mM}$ HEPES could simply reflect its higher concentration. However, the following experiment suggests an alternative explanation. In axons perfused with $120 \mathrm{mM} \mathrm{Na}^{+}$, exchanging external Tris for TMA results in a small 
suppression of $\mathrm{Na}^{+}$conductance (Fig. 11A). In the presence of $20 \mathrm{nM}$ STX, however, the currents in Tris are larger than those m TMA (Fig. 11B). This suggests that external Tris itself inhibits STX action (Fig. 11C) and may thus mask a relief of block by internal $\mathrm{NH}_{4}^{+}$ perfusion.

As a second test for periaxonal alkalinization, we examined STX block at an external $\mathrm{pH}$ of 6.2. If alkalinization occurred during internal $\mathrm{NH}_{4}{ }^{+}$perfusion, one would expect STX to be less susceptible to deprotonation at a $\mathrm{pH}$ further removed from its $\mathrm{pKa}$ of 8.25 . In 2 axons examined, the relief of STX block by internal $\mathrm{NH}_{4}{ }^{+}$was still present. However, the effect was significantly attenuated relative to that seen at an external $\mathrm{pH}$ of 7.8. Thus, the results from experiments to assess the influence of possible periaxonal alkalinization on the STX block neither conclusively demonstrate nor eliminate this alternative explanation.

\section{DISCUSSION}

Block of sodium channels in squid giant axons by external STX and TTX is dependent on the species of internal monovalent cation. Specifically, internal protons and the organic cations, ammonium $\left(\mathrm{NH}_{4}{ }^{+}\right)$and hydrazinium $\left(\mathrm{N}_{2} \mathrm{H}_{5}{ }^{+}\right)$antagonize toxin block of ion movement through open Nav channels. In contrast, changes in the concentration of $\mathrm{Na}^{+}$ions in the internal perfusate have no effect on toxin block. Consistent with this latter observation, it has been reported that toxin block of batrachotoxin-activated Nav channels in planar lipid bilayers is independent of internal $\mathrm{Na}^{+}$concentration (Moczydlowski et al., 1984). Additionally, we have observed that the ratios of outward currents carried by various monovalent cations reflect an apparent conductance sequence of $\mathrm{Na}^{+}>\mathrm{Li}^{+}=\mathrm{N}_{2} \mathrm{H}_{5}{ }^{+}>\mathrm{NH}_{4}{ }^{+}>$ $\mathrm{Rb}^{+}=\mathrm{K}^{+}$. This conductance sequence is similar to the permeability sequence for these monovalent cations in Nav channels of squid axons (Chandler and Meves, 1965: Yamamoto et al., 1985). The conductance sequence for only the metal cations is independent of the presence of STX, whereas the sequence for all cations tested differs in the presence and absence of toxin (Fig. 2). It thus appears that the inhibition of toxin block by $\mathrm{NH}_{4}{ }^{+}$or $\mathrm{N}_{2} \mathrm{H}_{5}{ }^{+}$ is not related to the relative permeability of these ions through the open unblocked Nav channel.

External monovalent metal cations have been shown to inhibit the binding of STX (Henderson et al., 1976; Weigele and Barchi, 1978) and TTX (Reed and Raftery, 1976: Frelin et al., 1981) in a manner which parallels their ability to impede ion flow through the Nav channel. However, recent STX binding studies in lobster nerves and membrane extracts of Drosophila brain (Strichartz et al., 1986) indicate that the dissociation constants for inhibition 
of $\mathrm{Na}^{+}$permeability by organic cations and for organic cation competition of STX binding are different. Strichartz et al. (1986) conclude that the site at which these cations inhibit STX binding is distinct from the channel pore and selectivity filter.

Other evidence which argues against the site of toxin binding being the selectivity filter has been obtained from: (1) trimethyloxonium (TMO), a carboxyl group alkylating reagent modification of Nav channels to give TTX-resistant channels with normal ionic selectivity (Spalding, 1980), (2) structure-activity studies of TTX, STX and its analogues which suggest that the binding site is located at the orifice of the Nav channel (Kao and Walker, 1982), and (3) the difference between the dissociation constants for $\mathrm{Na}^{+}$saturation of single channel conductance and for external $\mathrm{Na}^{+}$competition of TTX block (Moczydlowski et al., 1984).

External divalent cations (e.g. $\mathrm{Ca}^{2+}$ ) also alter toxin binding and block of Nav channels, but in a manner different from that described here for internal monovalent cations. Divalent ion effects cannot be attributed to either direct competition or a simple action of the screening of fixed negative surface charges (see Grissmer, 1984; Strichartz et al., 1986). Modulation of toxin binding by divalent metal cations appears to be due to electrostatic interactions with negative surface charges in the vicinity of the toxin binding site (see Green and Andersen, 1986).

The antagonism of STX block by internal $\mathrm{NH}_{4}{ }^{+}$does not appear to be a function of the direction of ion movement (Fig. 5; Rojas and Atwater, 1967). The reduction of STX block of inward $\mathrm{Na}^{+}$current during internal $\mathrm{NH}_{4}{ }^{+}$perfusion further suggests that occupancy of the Nav channel pore by $\mathrm{NH}_{4}{ }^{+}$is unlikely to be required for the inhibition of STX block.

While external $\mathrm{NH}_{4}{ }^{+}$does not impede toxin block, we did observe that replacing $\mathrm{TMA}^{+}$ with Tris ${ }^{+}$inhibits STX action. Competition of STX binding by external organic cations may involve size-exclusion at the extracellular site such that higher dissociation constants are observed for larger organic cations. In this regard, we observed that the cation, Tris (M.W. = $121 ; 5.5$ × $5.5 \times 6.4 \mathrm{~A}$ ) which is slightly larger than TMA (M.W. $=74 ; 5.5$ × 5.5 x $5.5 \AA$ ), is more effective in competing with the STX molecule. The absence of effects of external $\mathrm{NH}_{4}{ }^{+}$ (M.W: $=18 ; 3.0 \times 3.2 \times 3.4 \AA$ ) on STX block (see Fig. 4A) is consistent with this notion.

\section{The involvement of protons in $\mathrm{NH}_{4}^{+}$antagonism of toxin block}

The ability of ammonium ions to donate protons prompted an investigation of the effects of internal protons and their possible role in the $\mathrm{NH}_{4}{ }^{+}$effect. Increasing the internal proton concentration (lowering $\mathrm{pH}$ ) results in both block of the sodium channel and interference with the action of external STX and TTX. Both actions appear to reflect the ability of protons 
to pass through open sodium channels and interact with sites in the channel protein. In the absence of toxin, lowering the intracellular $\mathrm{pH}$ from 7.3 to 5.6 produced a voltage-dependent reduction in peak $\mathrm{Na}^{+}$current, whereby the proton block was less at more positive membrane potentials (see also Wanke et al., 1980). The estimated fractional electrical distance for the blocking site is $60 \%$ of the channel length from the cytoplasmic side. This hypothetical locus compares roughly with the blocking site for external protons (Woodhull, 1973) estimated to be $25 \%$ of the way through the membrane field from the external surface.

Interactions between protons and other molecules associating with or entering sodium channels from the opposite side have been reported. Begenisich and Danko (1983) observed that raising the intracellular permeant cation concentration reduced the block of Nav channels by external $\mathrm{H}^{+}$, thus, demonstrating competition between the permeant cations and $\mathrm{H}^{+}$for sites within the pore. We observed that the block of Nav channels by internal protons $(\mathrm{pH}$ 5.6) could be partially relieved by increasing the external buffer strength (HEPES concentration at a constant $\mathrm{pH}$ 7.8). This suggests that a proton gradient may exist through open Nav channels. Mozhayeva and Naumov (1983) directly measured proton currents through sodium channels in the node of Ranvier. Although the hydrogen to sodium permeability $\left(\mathrm{P}_{\mathrm{H}} / \mathrm{P}_{\mathrm{Na}}\right)$ ratio they determined from reversal potential measurements equals 252 , the channel conductance in a $\mathrm{Na}^{+}$-free acid solution is 50 times less than in control $\mathrm{Na}^{+}$ solutions. This suggests that protons can indeed ass through an open channel, but do so very slowly due to the binding to acidic group(s) in the channel.

Measurements of equilibrium block by STX at $\mathrm{pH}$ values of 7.3 and 5.6 (Fig. 8) indicate that the effectiveness of STX block is reduced by internal protons, such that there is a $63 \%$ relief of block (that is, increase of the relative $\mathrm{Na}^{+}$current) at $\mathrm{pH} 5.6$ compared to that observed at $\mathrm{p}$ 7.3. Relief of TTX block of peak $\mathrm{Na}^{+}$permeability by external protons at the node of Ranvier has been previously reported and attributed to proton-toxin competition for the same site (Ulbricht and Wagner, 1975). If protons and toxin molecules interact with the same site on squid axon sodium channels, it may not be a site where protons alone block the channel. The slight voltage dependence of the proton-induced relief of toxin block is in the opposite direction to that of proton block alone suggesting that the locus at which protons block Nav channels and compete with toxin binding are different. The existence of multiple binding sites for protons within the Nav channel has been postulated from previous studies of $\mathrm{H}^{+}$block of the Nav pore (Wanke et al., 1980; Begenisich and Danko, 1983).

The onset and recovery of $\mathrm{Na}^{+}$current from block upon perfusing with internal solutions of $\mathrm{pH} 5.6$ and 7.3, respectively, indicate that the time course of proton interaction 
with the Nav channel is a monotonic function. However, in the presence of toxin, a $\mathrm{pH}$ change from 5.6 to 7.3 results in a biphasic recovery of $\mathrm{Na}^{+}$current characterized by a transient increase in both inward and outward $\mathrm{Na}^{+}$current. The transient increase in $\mathrm{Na}^{+}$ current observed when the internal $\mathrm{pH}$ is raised from 5.6 to 7.3 may be attributed to the rapid dissociation of protons yielding unblocked channels which are blocked by STX with a slower association rate. As both protons and toxin molecules are positively charged, the apparent "competitive" interaction revealed by the transient increases in $\mathrm{Na}^{+}$current may reflect mutual Coulombic exclusion rather than mutual affinity for the same site. Given that the toxin concentration at the external surface of the axon should have reached equilibrium during this experiment, the kinetics of the current decay after this transient increase should reflect the toxin-channel interaction rather than loading of the periaxonal space. The time constant to reach a new equilibrium at $\mathrm{pH} 7.3$ (derived from the onset of action of $20 \mathrm{nM}$ STX at $\mathrm{pH} 7.3,10^{\circ} \mathrm{C}$ from Fig. 10) was approximately $72 \mathrm{sec}$ which may be compared to the

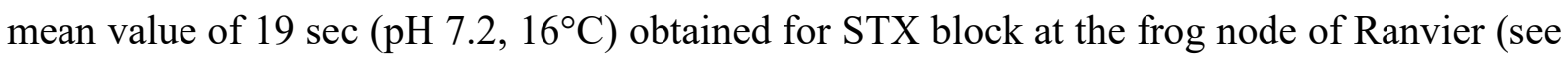
Tables 2 \& 3 of Wagner and Ulbricht, 1975). Given the differences in temperature and diffusion rates for the toxin at the node Ranvier and the squid giant axon (see Keynes et al., 1975), the only conclusion one can draw is that a slower association rate for STX was obtained under our experimental conditions.

Although there are similarities in the antagonism of toxin block of Nav channels by $\mathrm{NH}_{4}{ }^{+}, \mathrm{N}_{2} \mathrm{H}_{5}{ }^{+}$, and $\mathrm{H}^{+}$, the underlying mechanisms may differ. Perfusion with $300 \mathrm{mM} \mathrm{NH}_{4}^{+}$ may lead to an alkalinization of the periaxonal space and thus lower the effective (protonated) toxin concentration. The two different experimental protocols to address this possibility were to examine the effect of internal perfusion on STX block: (1) with an elevated extracellular buffer concentration, and (2) in the presence of a lower external $\mathrm{pH}$. The relief of STX block of Nav channels by internal $\mathrm{NH}_{4}{ }^{+}$was observed, though reduced, during both experimental procedures, and is thus consistent with a mechanism of competition by $\mathrm{NH}_{4}{ }^{+}$for a toxin binding site. In addition, comparison of $\mathrm{NH}_{4}{ }^{+}$antagonism of STX and TTX (zwitterion with a $\mathrm{pKa}$ of 8.8) action indicates that the relief of toxin block is not due to a change in the degree of ionization of the toxin molecule. While these experiments lend support to a direct interaction between $\mathrm{NH}_{4}{ }^{+}$and a toxin binding site, we cannot completely rule out the possibility that periaxonal $\mathrm{pH}$ changes play a role in this phenomenon. This question will perhaps remain unresolved until accurate measurements of $\mathrm{pH}$ changes in the periaxonal space during perfusion with $\mathrm{NH}_{4}^{+}$can be performed. 
In summary, we have demonstrated an apparent trans channel interaction between the organic cations, $\mathrm{NH}_{4}^{+}$and $\mathrm{N}_{2} \mathrm{H}_{5}{ }^{+}$, in the internal compartment of the squid giant axon and STX or TTX molecules which bind to a site(s) on the external portion of the voltage-gated sodium channel. The apparent reduction in toxin potency observed under these conditions is similar to that seen by lowering internal $\mathrm{pH}$. Our results support the notion that interaction of permeant cations with toxin binding sites may be more complicated than simple competition of ligands from the same cellular compartment.

\section{ACKNOWLEDGEMENTS}

The authors thank Dr. Olaf Andersen for constructive suggestions during this project. This work was supported by National Science Foundation grant (BNS 8211580) to G.S. Oxford and a Wellcome Trust travel award to D.J. Adams.

The authors declare no competing financial interests.

Author contributions: G.S. Oxford, P Forscher, P.K. Wagoner and D.J. Adams designed and performed experiments, analyzed and interpreted data, and co-wrote the paper. 


\section{REFERENCES}

Barchi, R.L, and J.B. Weigele. 1979. Characteristics of saxitoxin binding to the sodium channel of sarcolemma isolated from rat skeletal muscle. J. Physiol. 295:383-396. https://doi.org/10.1113/jphysiol.1979.sp012975.

Begenisich, T., and M. Danko. 1983. Hydrogen ion block of the sodium pore in squid giant axons. J. Gen. Physiol. 82:599-618. https://doi.org/10.1085/jgp.82.5.599.

Binstock, L, and H. Lecar. 1969. Ammonium ion conductance in the squid giant axon. $J$. Gen. Physiol. 53:342-361. https://doi.org/10.1085/jgp.53.3.342.

Brodwick, M.S., and D.C. Eaton. 1978. Sodium channel inactivation in squid axon is removed by high internal pH or tyrosine-specific reagents. Science. 200:1494-1496. https://doi.org/10.1126/science.26973.

Carbone, E., P.L Testa, and E. Wanke. 1981. Intracellular pH and ionic channels in the Loligo vulgaris giant axon. Biophys. J. 35:393-413. https://doi.org/10.1016/S00063495(81)84798-4.

Catterall, W.A. 1992. Cellular and molecular biology of voltage-gated sodium channels. Physiol. Rev. 72:S15-48. https://doi.org/10.1152/physrev.1992.72.suppl 4.S15.

Catterall, W.A. 1995. Structure and function of voltage-gated ion channels. Ann. Rev. Biochem. 64:493-531. https://doi.org/10.1146/annurev.bi.64.070195.002425.

Chandler, W.K., and H. Meves. 1965. Voltage clamp experiments on internally perfused giant axons. J. Physiol. 180:788-820. https://doi.org/10.1113/jphysiol.1965.sp007732.

Colquhoun, D., R. Henderson, and J.M. Ritchie. 1972. The binding of labelled tetrodotoxin to non-myelinated nerve fibres. J. Physiol. 227:95-126.

https://doi.org/10.1113/jphysiol.1972.sp010022.

Colquhoun, D., and J.M. Ritchie. 1972. The kinetics of the interaction between tetrodotoxin and mammalian non-myelinated nerve fibers. Mol. Pharmacol. 8:285-292.

Cuervo, LA., and W.J. Adelman. 1970. Equilibrium and kinetic properties of the interaction between tetrodotoxin and the excitable membrane of the squid giant axon. J. Gen. Physiol. 55:309-335. https://doi.org/10.1085/jgp.55.3.309.

Frelin, C., P. Vigne, and M. Lazdunski. 1981. The specificity of the sodium channel for monovalent cations. Eur. J. Biochem. 119:437-442. https://doi.org/10.1111/j.14321033.1981.tb05627.x.

Green, W.N., and O.S. Andersen. 1986. Surface charges near the guanidinium binding site. Ann. NY Acad. Sci. 47:306-312. https://doi.org/10.1111/j.1749-6632.1986.tb15577.x. 
Grissmer, S. 1984. Effect of various cations and anions on the action of tetrodotoxin and saxitoxin on frog myelinated nerve fibers. Pflügers Archiv. 402:353-359. https://doi.org/10.1007/BF00583935.

Hahin, R, and G. Strichartz. 1981. Effects of deuterium oxide on the rate and dissociation constants for saxitoxin and tetrodotoxin action. Voltage-clamp studies on frog myelinated nerve. J. Gen. Physiol. 78:113-139. https://doi.org/10.1085/jgp.78.2.113.

Henderson, R., J.M. Ritchie, and G.R. Strichartz 1974. Evidence that tetrodotoxin and saxitoxin act at a metal cation binding site in the sodium channels of nerve membrane. Proc. Natl. Acad. Sci. USA. 71:3936-3940. https://doi.org/10.1073/pnas.71.10.3936.

Henderson, R., and J.H. Wang. 1972. Solubilization of specific tetrodotoxin-binding component from garfish olfactory nerve membrane. Biochemistry. 11:4565-4569. https://doi.org/10.1021/bi00774a022.

Hille, B. 1968. Pharmacological modifications of the sodium channels of frog nerve. J. Gen. Physiol. 51:199-219. https://doi.org/10.1085/jgp.51.2.199.

Hille, B. 1975a. The receptor for tetrodotoxin and saxitoxin. A structural hypothesis. Biophys. J. 15:615-619. https://doi.org/10.1016/S0006-3495(75)85842-5.

Hille, B. 1975b. Ionic selectivity, saturation, and block in sodium channels: A four barrier model. J. Gen. Physiol. 66:535-560. https://doi.org/10.1085/jgp.66.5.535.

Kao, CY., and A. Hishiyama. 1965. Action of saxitoxin on peripheral neuromuscular systems. J. Physiol. 180:50-66.

Kao, C.Y., and S.E. Walker. 1982. Active groups of saxitoxin and tetrodotoxin as deduced from actions of saxitoxin analogues of frog muscle and squid axon. J. Physiol. 323:619-637. https://doi.org/10.1113/jphysiol.1982.sp014095.

Kao, P.N., M.R. James-Kracke, and C.Y. Kao. 1983. The active guanidinium group of saxitoxin and neosaxitoxin identified by the effects of $\mathrm{pH}$ on their activities on squid axon. Pflügers Archiv. 398:199-203. https://doi.org/10.1007/BF00657151.

Keynes, R.D., F. Bezanilla, E. Rojas, and R.E: Taylor. 1975. The rate of action of tetrodotoxin on sodium conductance in the squid giant axon. Phil. Trans. Royal Soc. Lond. B Biol. Sci. 270:365-373. https://doi.org/10.1098/rstb.1975.0016.

Kirsch, G.E., and T. Narahashi. 1978. 3,4-Diaminopyridine. A potent new potassium channel blocker. Biophys. J. 22:507-512. https://doi.org/10.1016/S0006-3495(78)85503-9.

Krueger, B.K., J.F. Worley, and R.J. French. 1983. Single sodium channels from rat brain incorporated into planar lipid bilayer membranes. Nature. 303:172-175. https://doi.org/10.1038/303172a0. 
Moczydlowski, E., S.S. Garber, and C. Miller. 1984. Batrachotoxin-activated $\mathrm{Na}^{+}$channels in planar lipid bilayers. Competition of tetrodotoxin block by $\mathrm{Na}^{+}$. J. Gen. Physiol. 84:665-686. https://doi.org/10.1085/jgp.84.5.665.

Moczydlowski, E., S. Hall, S.S. Garber, G..S. Strichartz, and C. Miller. 1984. Voltagedependent blockade of muscle $\mathrm{Na}^{+}$channels by guanidinium toxins. Effect of toxin charge. J. Gen. Physiol. 84:687-704. https://doi.org/10.1085/jgp.84.5.687.

Moore, J.W., M.P. Blaustein, N.C. Anderson, and T. Narahashi. 1967. Basis of tetrodotoxin's selectivity in blockage of squid axons. J. Gen Physiol. 50:1401-1411.

https://doi.org/10.1085/jgp.50.5.1401.

Mozhayeva, G.N., and A.P. Naumov. 1983. The permeability of sodium channels to hydrogen ions in nerve fibres. Pflügers Archiv. 396:163-173. https://doi.org/10.1007/BF00615521.

Narahashi, T. 1974. Chemicals as tools in the study of excitable membranes. Physiol. Rev. 54:813-889. https://doi.org/10.1152/physrev.1974.54.4.813.

Oxford, G.S. 1981. Some kinetic and steady-state properties of sodium channels after removal of inactivation. J. Gen. Physiol. 77:1-22. https://doi.org/10.1085/jgp.77.1.1.

Oxford, G.S., and D.J. Adams. 1981. Permeant cations alter K channel kinetics and permeability. Biophys. J. 33:70a (abstract). https://www.cell.com/biophysj/pdf/S00063495(81)84892-8.pdf

Oxford, G.S., P. Forscher, and D.J. Adams. 1984. Intracellular $\mathrm{NH}_{4}{ }^{+}$and $\mathrm{H}^{+}$ions antagonize block of sodium channels by saxitoxin and tetrodotoxin. Biophys. J. 45:13a (abstract). https://www.cell.com/biophysj/pdf/S0006-3495(84)84174-0.pdf

Oxford, G.S., C.H. Wu, and T. Narahashi. 1978. Removal of sodium channel inactivation in squid giant axons by N-bromoacetamide. J. Gen. Physiol. 71:227-247. https://doi.org/10.1085/jgp.71.3.227.

Oxford, G.S., and J.Z. Yeh. 1985. Interactions of monovalent cations with sodium channels in squid axon. I. Modification of physiological inactivation gating. J. Gen. Physiol. 85:583-602. https://doi.org/10.1085/jgp.85.4.583.

Reed, J.K., and M.A. Raftery. 1976. Properties of the tetrodotoxin binding component in plasma membranes isolated from Electrophorus electricus. Biochemistry. 15:944-953. https://doi.org/10.1021/bi00650a002.

Roos, A., and W.F. Boron. 1981. Intracellular pH. Physiol. Rev. 61:296-434. https://doi.org/10.1152/physrev.1981.61.2.296. 
Rojas, E. and I. Atwater. 1967. Effect of tetrodotoxin on the early outward currents in perfused giant axons. Proc. Natl. Acad. Sci. USA. 57:1350-1355. https://doi.org/10.1073/pnas.57.5.1350.

Spalding, B.C. 1980. Properties of toxin-resistant sodium channels produced by chemical modification in frog skeletal muscle. J. Physiol. 305:485-500. https://doi.org/10.1113/jphysiol.1980.sp013377.

Strichartz, G. 1984. Structural determinants of the affinity of saxitoxin for neuronal sodium channels. Electrophysiological studies on frog peripheral nerve. J. Gen. Physiol. 84:281-305. https://doi.org/10.1085/jgp.84.2.281.

Strichartz, G., T. Rando, S. Hall, J. Gitschier, L. Hall, B. Magnani, and C. Hansen Bay. 1986. On the mechanism by which saxitoxin binds to and blocks sodium channels. Ann. NY Acad. Sci. 479:96-112. https://doi.org/10.1111/j.1749-6632.1986.tb15564.x.

Ulbricht, W. 1981. Kinetics of drug action and equilibrium results at the node of Ranvier. Physiol. Rev. 61:785-828. https://doi.org/10.1152/physrev.1981.61.4.785.

Ulbricht, W., and H.-H. Wagner. 1975. The influence of $\mathrm{pH}$ on equilibrium effects of tetrodotoxin on myelinated nerve fibres of Rana esculenta. J. Physiol. 252:159-184. https://doi.org/10.1113/jphysiol.1975.sp011139.

Ulbricht, W., and H.-H. Wagner. 1975. The reaction between tetrodotoxin and membrane sites at the node of Ranvier: its kinetics and dependence on pH. Phil. Trans. Royal Soc. Lond. B Biol. Sci. 270:353-363. https://doi.org/10.1098/rstb.1975.0015.

Wagner, H.-H. and W. Ulbricht. 1975. The rates of saxitoxin action and saxitoxintetrodotoxin interaction at the node of Ranvier. Pflügers Archiv. 359:297-315. https://doi.org/10.1007/BF00581441.

Wanke, E., E. Carbone, and P.L. Testa. 1980. The sodium channel and intracellular $\mathrm{H}^{+}$ blockage in squid axons. Nature. 287:62-63. https://doi.org/10.1038/287062a0.

Weigele, J.B., and R.L. Barchi. 1978. Saxitoxin binding to the mammalian sodium channel. Competition by monovalent and divalent cations. FEBS Lett. 95:49-53. https://doi.org/10.1152/physrev.1981.61.4.785.

Woodhull, A. 1973. Ionic blockage of sodium channels in nerve. J. Gen. Physiol. 61:687-708. https://doi.org/10.1085/jgp.61.6.687.

Yamamoto, D., J.Z. Yeh, and T. Narahashi. 1985. Interactions of permeant cations with sodium channels of squid axon membrane. Biophys. J. 48:361-368. https://doi.org/10.1016/S0006-3495(85)83792-9. 
TABLE 1. Composition of External and Internal Solutions

\begin{tabular}{|l|c|c|c|c|c|c|c|}
\hline \multicolumn{1}{|c|}{ External Soln. } & Na & TMA & Tris & NH4 & $\mathbf{C a}^{2+\mathbf{a}}$ & $\mathbf{C 1}$ & HEPES $^{\mathbf{b}}$ \\
\hline $450 \mathrm{Na} / /$ & 450 & & & & 50 & 545 & 5 \\
\hline $450 \mathrm{TMA}, 5 \mathrm{HEPES} / /$ & & 450 & & & 50 & 545 & 5 \\
\hline $450 \mathrm{TMA}, 25 \mathrm{HEPES} / /$ & & 410 & & & 50 & 510 & 25 \\
\hline $450 \mathrm{Tris} / /$ & & & 450 & & 50 & 545 & 5 \\
\hline $450 \mathrm{NH}_{4} / /$ & & & & 450 & 50 & 545 & 5 \\
\hline
\end{tabular}

\begin{tabular}{|l|c|c|c|c|c|c|}
\hline \multicolumn{1}{|c|}{ Internal Soln. } & Na & Cs & F & Glucose & Sucrose & MOPS $^{\mathbf{d}}$ \\
\hline$/ / 300 \mathrm{Na}^{\mathbf{c}}$ & 300 & & 50 & 250 & 345 & 10 \\
\hline$/ / 100 \mathrm{Na}, 200 \mathrm{Cs}$ & 100 & 200 & 50 & 250 & 345 & 10 \\
\hline
\end{tabular}

TMA, tetramethylammonium; Tris, tris(hydroxymethyl)aminomethane; HEPES, 4-(2-

hydroxyethyl)-1-piperazineethanesulfonic acid; MOPS, 3-( $N$-morpholino)propanesulfonic acid; MES, 2-( $N$-morpholino)ethanesulfonic acid.

${ }^{\mathbf{a}}$ In one series of experiments $10 \mathrm{mM} \mathrm{CaCl}_{2}$ and $40 \mathrm{mM} \mathrm{MgC1}_{2}$ were substituted. No significant differences were observed by this substitution.

${ }^{\mathbf{b}}$ External solutions were buffered to $\mathrm{pH} 7.8$.

${ }^{\mathbf{c}}$ Equimolar substitutions of monovalent cations $\left(\mathrm{Li}^{+}, \mathrm{Cs}^{+}, \mathrm{NH}_{4}{ }^{+}, \mathrm{N}_{2} \mathrm{H}_{5}{ }^{+}\right.$, and $\mathrm{K}^{+}$) were made for $\mathrm{Na}^{+}$. ${ }^{d} \mathrm{pH}$ was adjusted to 7.3 for most experiments. $\left.10 \mathrm{mM} \mathrm{MES} \mathrm{(} \mathrm{pK}_{\mathrm{a}} 6.2\right)$ was substituted for MOPS $\left(\mathrm{pK}_{\mathrm{a}}\right.$ 7.2) in experiments where the $\mathrm{pH}$ was reduced to 5.6. 


\section{FIGURE LEGENDS}

Figure 1. Internal ammonium perfusion reduces STX block of $\mathrm{K}^{+}$currents through sodium channels. (A) Potassium currents through sodium channels (and potassium channels) in the absence of STX. (B) Currents from the same axon as (A) following the addition of $10 \mathrm{nM}$ STX to the bathing medium. Note the selective reduction of sodium channel current. (C) Outward ammonium currents following washout of STX and substitution of internal $\mathrm{K}^{+}$by $\mathrm{NH}_{4}{ }^{+}$. (D) Reintroduction of 10 nM STX to the external bath has very little effect on the amplitude of $\mathrm{NH}_{4}{ }^{+}$ currents through the sodium channels. Scale markers represent $0.36 \mathrm{~mA} / \mathrm{cm}^{2}$ and 2 $\mathrm{ms}(\mathrm{A}$ and $\mathrm{B})$, or $0.72 \mathrm{~mA} / \mathrm{cm}^{2}$ and $2 \mathrm{~ms}(\mathrm{C}$ and $\mathrm{D})$. Temperature $=10.2^{\circ} \mathrm{C}$.

Figure 2. Magnitude of outward current through sodium channels for various internal monovalent cations in the presence and absence of 10-20 nM STX. Solid bars represent mean peak outward currents at $+100 \mathrm{mV}$ for the indicated internal cations and concentrations $(\mathrm{mM})$ normalized to the values obtained in the same axons at $300 \mathrm{mM} \mathrm{Na}^{+}$. Open bars represent similar data obtained in the presence of either 10 or $20 \mathrm{nM}$ STX and again normalized to the current obtained in $300 \mathrm{mM}$ $\mathrm{Na}^{+}$. Numbers over each set of bars correspond to the number of experiments for both toxin and control conditions.

Figure 3. Comparison of STX block in $\mathrm{Na}^{+}$-perfused and $\mathrm{NH}_{4}{ }^{+}$-perfused axon exhibiting comparable current magnitudes. (A) Outward sodium currents in an axon perfused with //100 Na. (B) Outward ammonium currents from the same axon following perfusion with //300 $\mathrm{NH}_{4}$. (C) Outward currents following return to //100 Na and addition of $20 \mathrm{nM}$ STX to the external 450 TMA solution. (D) Currents in the presence of STX during perfusion with //300 $\mathrm{NH}_{4}$. Note the change in vertical scales between A,B and C,D.

Figure 4. Relative peak sodium channel currents following exposure to $20 \mathrm{nM}$ STX as a function of membrane potential. Data points represent the ratio of peak current in STX to that in the absence of toxin. (A) External ammonium ions (open symbols) do not affect STX block compared to that seen with $450 \mathrm{mM} \mathrm{Na}$ (closed symbols). Circles and triangles represent 2 separate axons. (B) Internal ammonium 
perfusion reduces STX block of inward sodium currents. Closed symbols are from 2 axons (different from A) perfused with //120 Na and then perfused with //300 NH 4 (open symbols). Reversal potential observed for both conditions was $+33 \mathrm{mV}$.

Figure 5. Internal ammonium increases inward sodium currents in the presence of STX. Ionic current responses to membrane potential steps to $-50,-40,-30,-20$, $-10,0$, and $+10 \mathrm{mV}$ in an axon exposed to $20 \mathrm{nM}$ STX in $450 \mathrm{Na}$ and internally perfused first with //120 Na (A) and then //300 $\mathrm{NH}_{4}$ (B) A comparison of the records at 0 $\mathrm{mV}$ is shown in $\mathrm{C}$, where the larger current was obtained in $/ / 300 \mathrm{NH}_{4}$.

Figure 6. Ammonium perfusion reduces TIX block of sodium channels. (A) Outward currents at $+100 \mathrm{mV}$ for an axon perfused consecutively with //120 Na and //300 $\mathrm{NH}_{4}$. External solution was 450 TMA. Note the identity of peak current in the two solutions. (B) Outward currents under similar conditions following addition of $10 \mathrm{nM}$ TTX to the bath. Records labelled 1 and 2 were obtained before and after perfusion with //300 $\mathrm{NH}_{4}$, respectively. Note the increase of outward current with ammonium perfusion. Increased outward steady-state current with //300 $\mathrm{NH}_{4}$ in both cases probably reflects $\mathrm{NH}_{4}{ }^{+}$movement through $\mathrm{K}$ channels not blocked by DAP. Note the 4-fold difference in vertical scales between $\mathrm{A}$ and $\mathrm{B}$.

Figure 7. Increasing external buffer strength partially relieves block of sodium channels by internal protons. Families of sodium currents obtained consecutively in 450Na containing $5 \mathrm{mM}$ HEPES, $25 \mathrm{mM}$ HEPES, and return to $5 \mathrm{mM}$ HEPES during perfusion with internal $/ / 100 \mathrm{Na}$ at $\mathrm{pH} 5.6(\mathrm{~A}, \mathrm{~B}, \mathrm{C})$ and then at $\mathrm{pH} 7.3$ (D,E,F). Membrane potential steps to $-60,-40,-20,0,20,40,60$, and $80 \mathrm{mV}$ from a holding potential of $-80 \mathrm{mV}$.

Figure 8. Low intracellular $\mathrm{pH}$ reduces block of sodium channels by external STX. Data points represent ratios of peak sodium currents obtained in the presence of $20 \mathrm{nM}$ STX to those in the absence of toxin at several membrane potentials. Different shaped symbols apply to each of 3 axons, while corresponding closed and open symbols were obtained at internal $\mathrm{pH}$ values of 7.3 and 5.6, respectively. Dashed lines indicate the 
mean current ratios at $\mathrm{pH} 5.6$ and 7.3 calculated from all data points above the reversal potential $(+38 \mathrm{mV})$. Experimental solutions were $450 \mathrm{Na} / / 100 \mathrm{Na}$ for each axon.

Figure 9. Peak sodium current measured at $0 \mathrm{mV}$ at various times following a change in internal $\mathrm{pH}$ from 5.6 to 7.3 in the presence of external $20 \mathrm{nM}$ STX. The data are plotted as a function of time (open circles) and reveal a transient recovery of current magnitude. Solid line fit by eye through the data points. Families of currents at several membrane potentials were obtained at the times indicated by the letters $(a, b, c)$ and are depicted in the upper panel. Experimental solutions were $450 \mathrm{Na} / / 100 \mathrm{Na}$.

Figure 10. Sodium current transients recorded at $0 \mathrm{mV}$ in 4 axons at various times during the transition between internal $\mathrm{pH} 5.6$ and 7.3. Procedures and solutions identical to those of Figure 9. Data from each experiment has been shifted along the time axis to the estimated time of internal solution exchange at the recording region of each axon (0 min.).

Figure 11. External Tris ${ }^{+}$inhibits block of sodium channels by STX. Outward sodium currents were recorded consecutively at $+100 \mathrm{mV}$ in the following external solutions: 450 TMA, 5 HEPES//; 450 Tris//; and 450 TMA, 25 HEPES//. Measurements were made in the absence (A) and presence (B) of $20 \mathrm{nM}$ STX. Note the increase in current with Tris $^{+}$in the presence of toxin. Ratios of current in toxin to control values are plotted in (C) for several membrane potentials in 450 TMA, 5 HEPES (triangles), 450 Tris (squares), and 450 TMA, 25 HEPES (circles). Internal solution was //120 Na. 
bioRxiv preprint doi https://doi. org/10.1101/2021.12 21.473550; this version posted December 22, 2021. The copyright holder for this preprint (which was not certified by peer review) is the author/funder, who has granted bioRxiv a license to display the preprint in perpetuity. It is made available under aCC-BY 4.0 International license.

\section{Figure 1.}

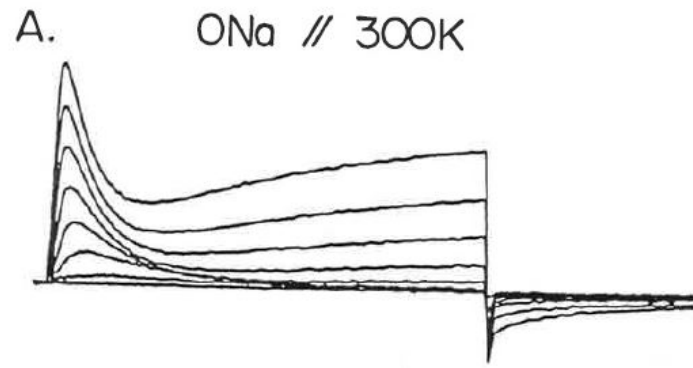

B. ONa,STX // 30OK

C. ONa // $300 \mathrm{NH}_{4}$
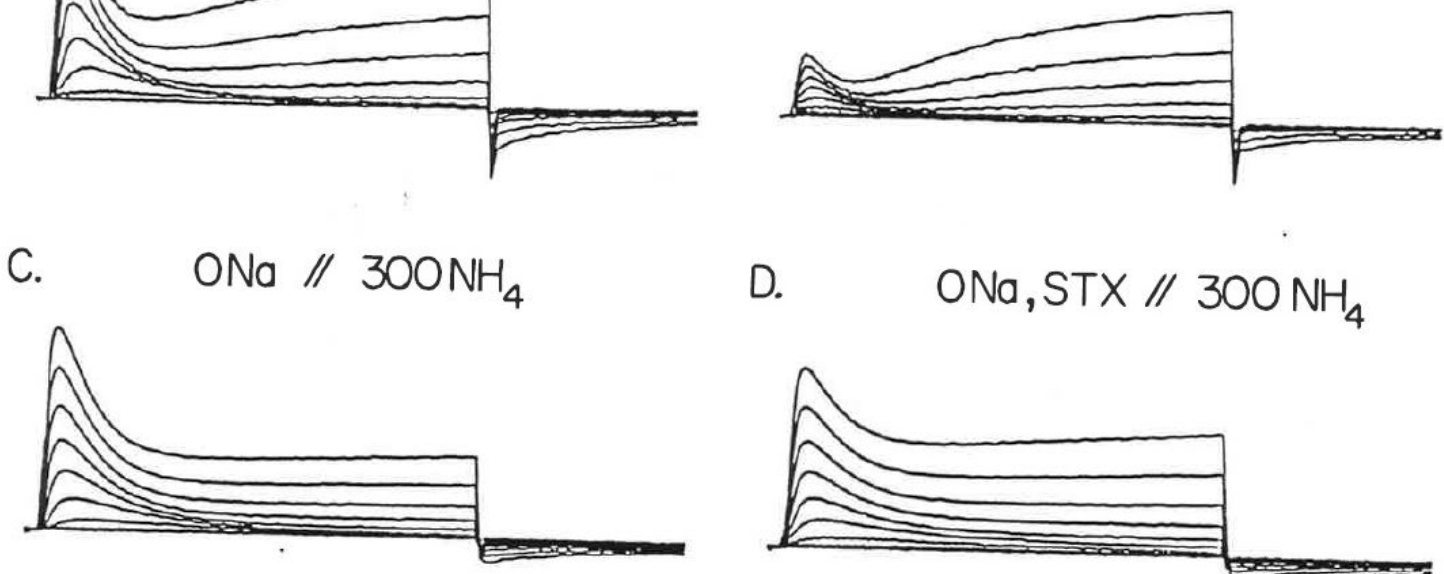

D.

ONa,STX // $300 \mathrm{NH}_{4}$

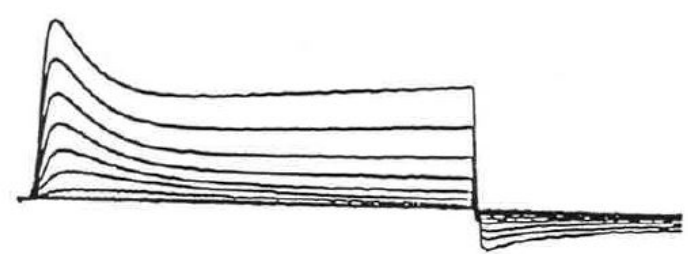


Figure 2.

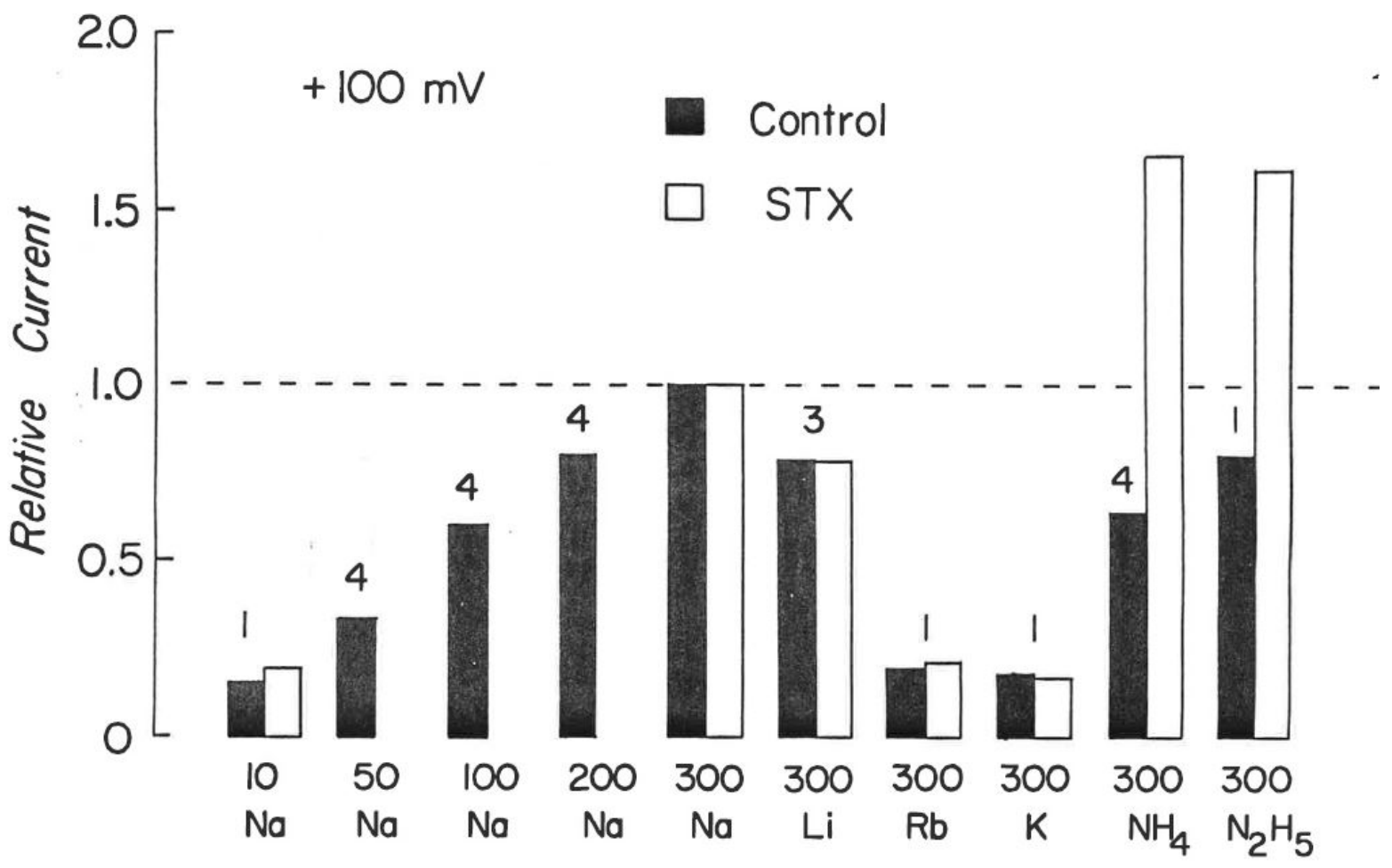


bioRxiv preprint doi: https://doi org/101101/2021.12 21.473550; this version posted December 22, 2021. The copyright holder for this preprint (which was not certified by peer review) is the author/funder, who has granted bioRxiv a license to display the preprint in perpetuity. It is made available under aCC-BY 4.0 International license.

\section{Figure 3.}

A.

450TMA// $100 \mathrm{Na}$

B.

450TMA // $300 \mathrm{NH}_{4}$
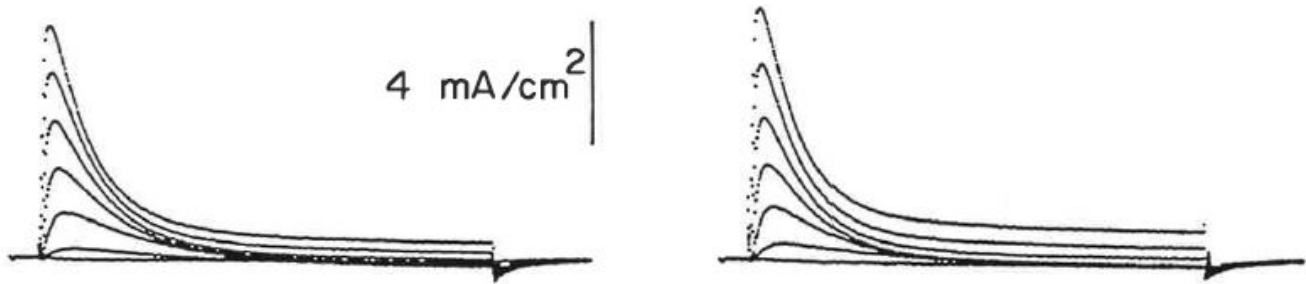

C. 2OSTX // $100 \mathrm{Na}$

D. 20 STX // $300 \mathrm{NH}_{4}$

$2 \mathrm{~mA} / \mathrm{cm}^{2}$
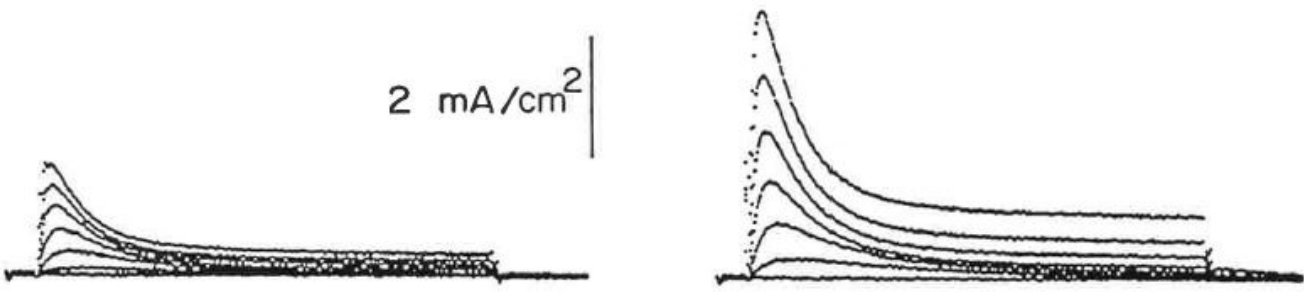

$2 \mathrm{~ms}$ 
bioRxiv preprint doi: https://doi org/10.1101/2021.12.21.473550; this version posted December 22, 2021. The copyright holder for this preprint (which was not certified by peer review) is the author/funder, who has granted bioRxiv a license to display the preprint in perpetuity. It is made available under aCC-BY 4.0 International license.

Figure 4.

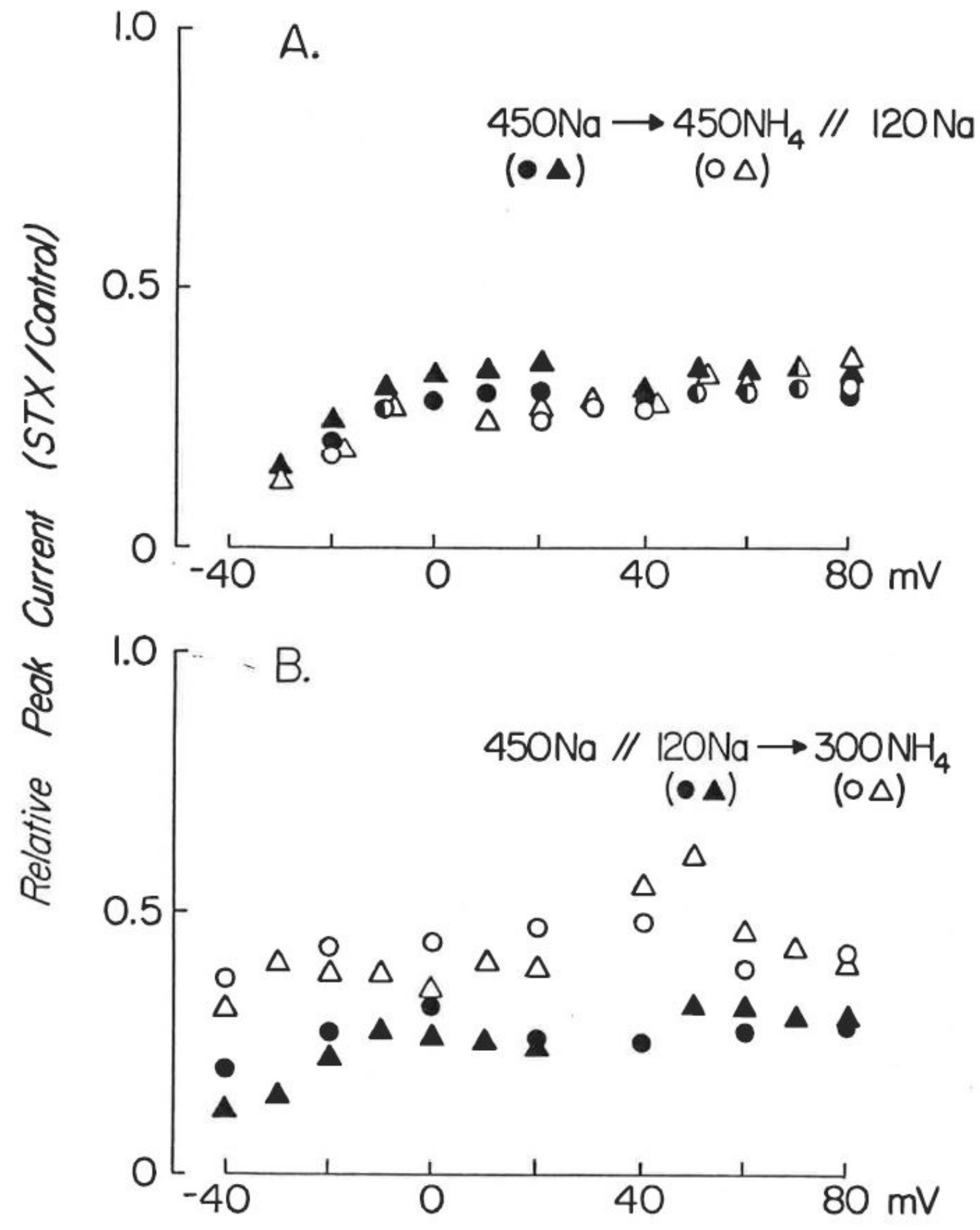


bioRxiv preprint doi: https://doi.org/10.1101/2021.12.21.473550; this version posted December 22, 2021. The copyright holder for this preprint (which was not certified by peer review) is the author/funder, who has granted bioRxiv a license to display the preprint in perpetuity. It is made available under aCC-BY 4.0 International license.

\section{Figure 5.}

\section{A. STX// $120 \mathrm{Na}$ B. STX// $300 \mathrm{NH}_{4}$ C. $\mathrm{O} \mathrm{mV}$}
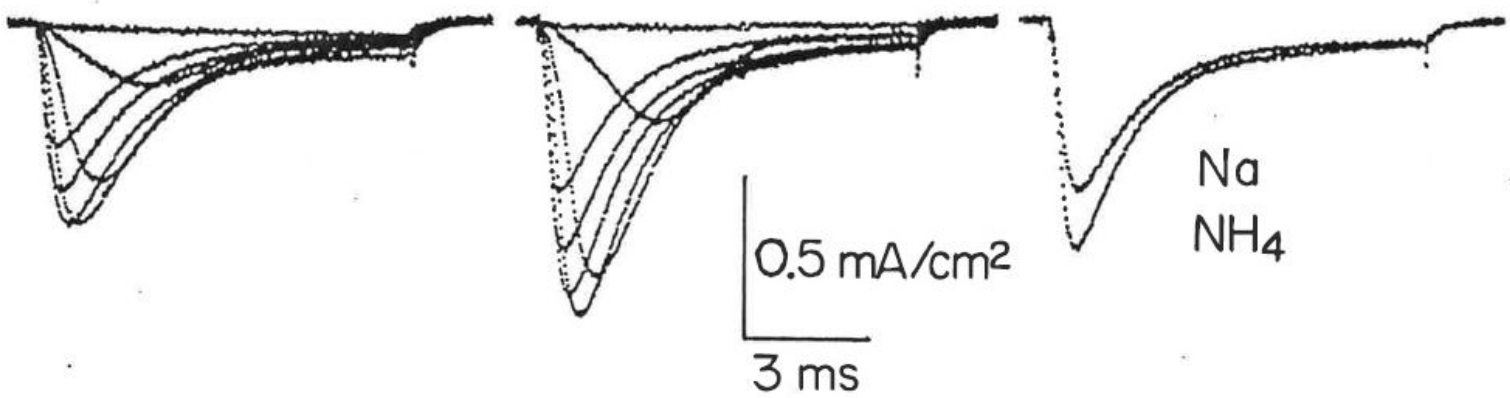
bioRxiv preprint doi: https://doi org/10.1101/2021.12.21.473550; this version posted December 22, 2021. The copyright holder for this preprint (which was not certified by peer review) is the author/funder, who has granted bioRxiv a license to display the preprint in perpetuity. It is made available under aCC-BY 4.0 International license.

Figure 6.

A.

CONTROL

B.

$10 \mathrm{nM}$ TTX
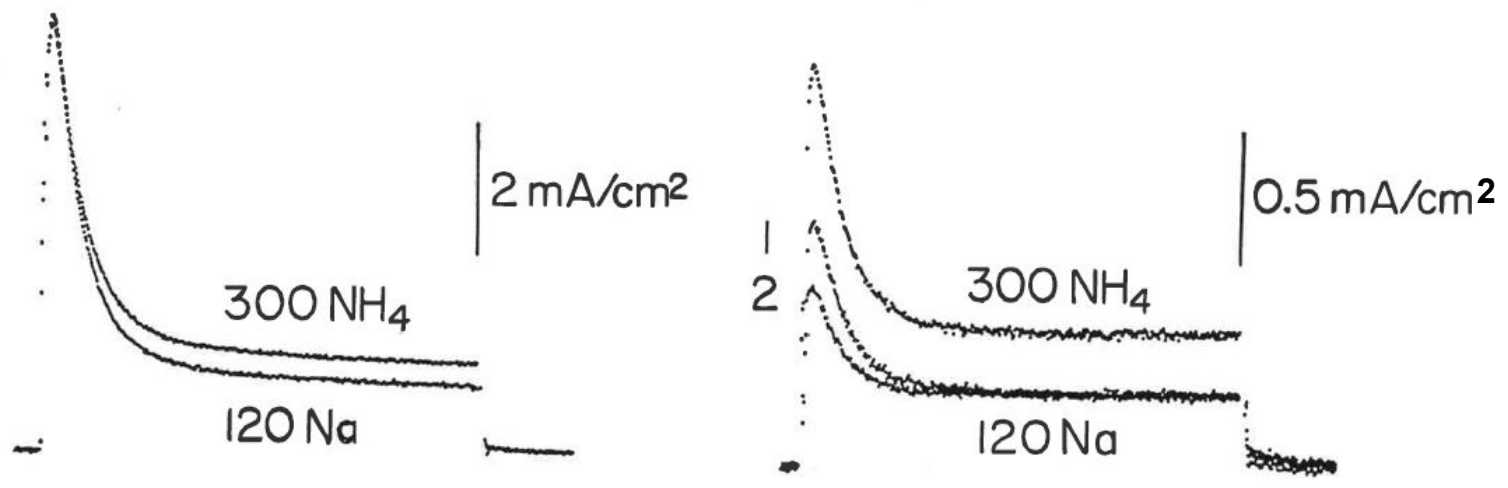
bioRxiv preprint doi: https://doi org/10.1101/2021.12.21.473550; this version posted December 22, 2021. The copyright holder for this preprint (which was not certified by peer review) is the author/funder, who has granted bioRxiv a license to display the preprint in perpetuity. It is made available under aCC-BY 4.0 International license.

\section{Figure 7.}

5 HEPES

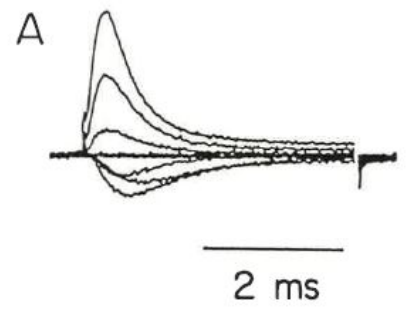

D

$\mathrm{pH} 7.3$

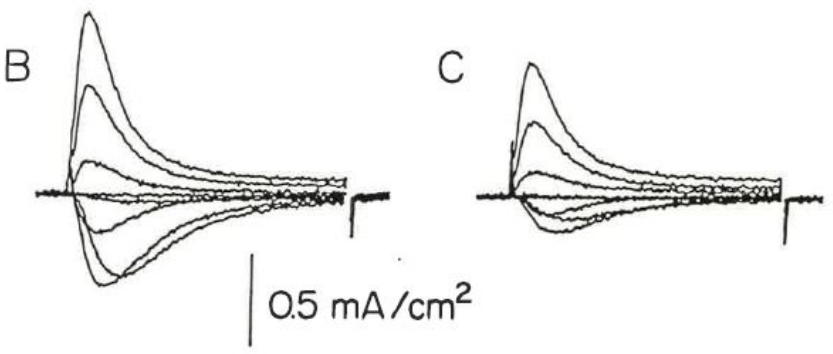

E

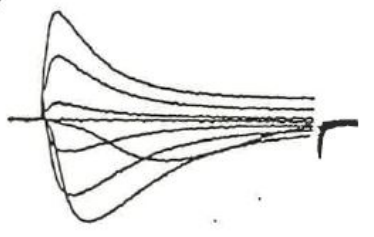

F

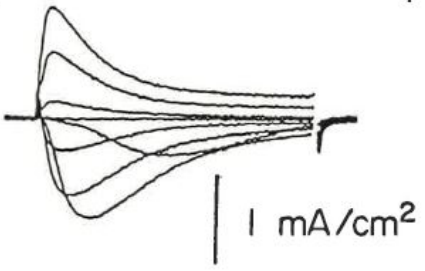

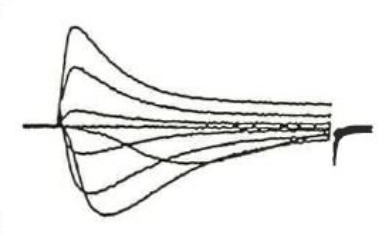


bioRxiv preprint doi: https://doi org/10.1101/2021.12.21.473550; this version posted December 22, 2021. The copyright holder for this

preprint (which was not certified by peer review) is the author/funder, who has granted bioRxiv a license to display the preprint in perpetuity. It is made available under aCC-BY 4.0 International license.

Figure 8.

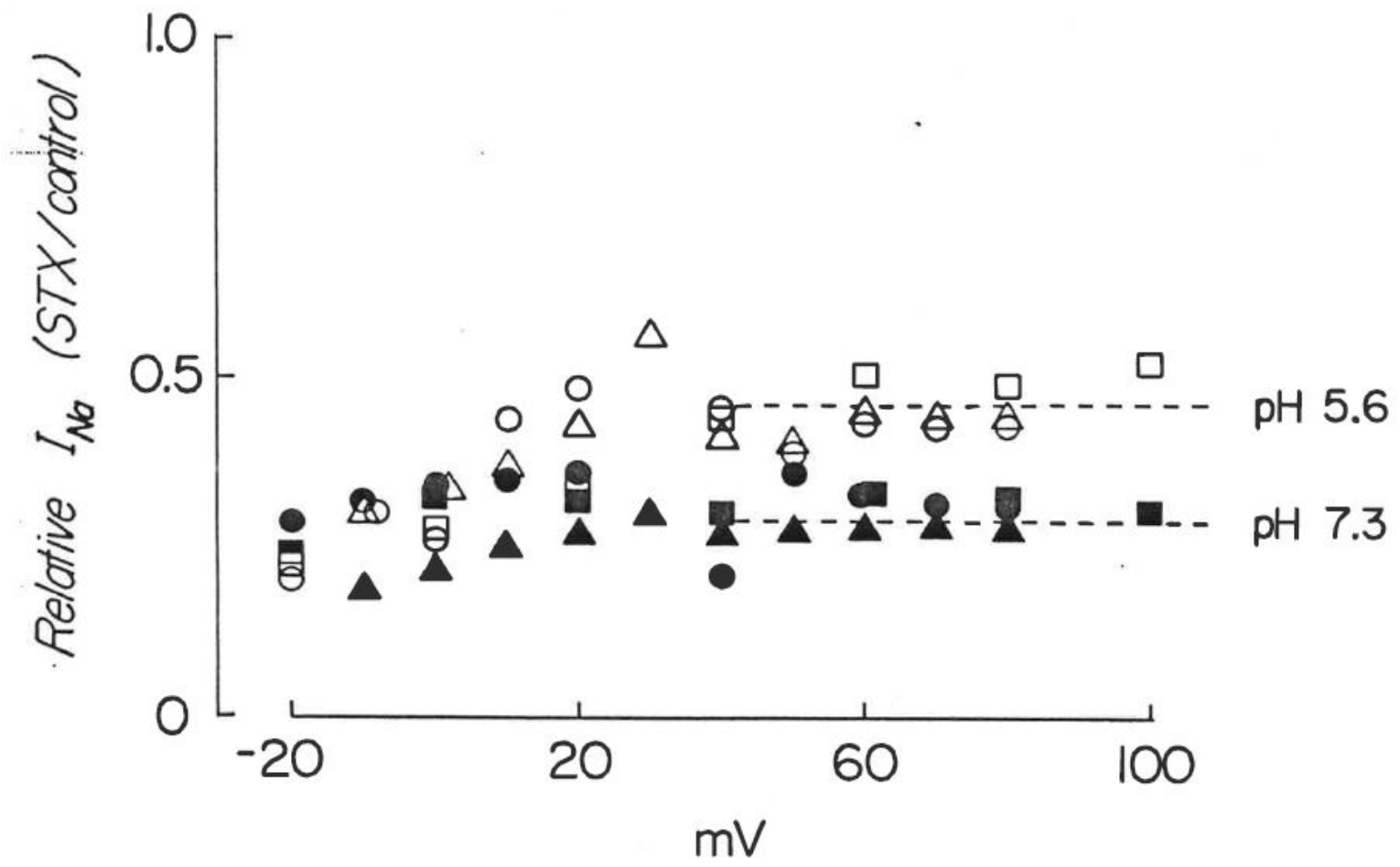


bioRxiv preprint doi: https://doi org/10.1101/2021.12.21.473550; this version posted December 22, 2021. The copyright holder for this preprint (which was not certified by peer review) is the author/funder, who has granted bioRxiv a license to display the preprint in perpetuity. It is made available under aCC-BY 4.0 International license.

Figure 9.
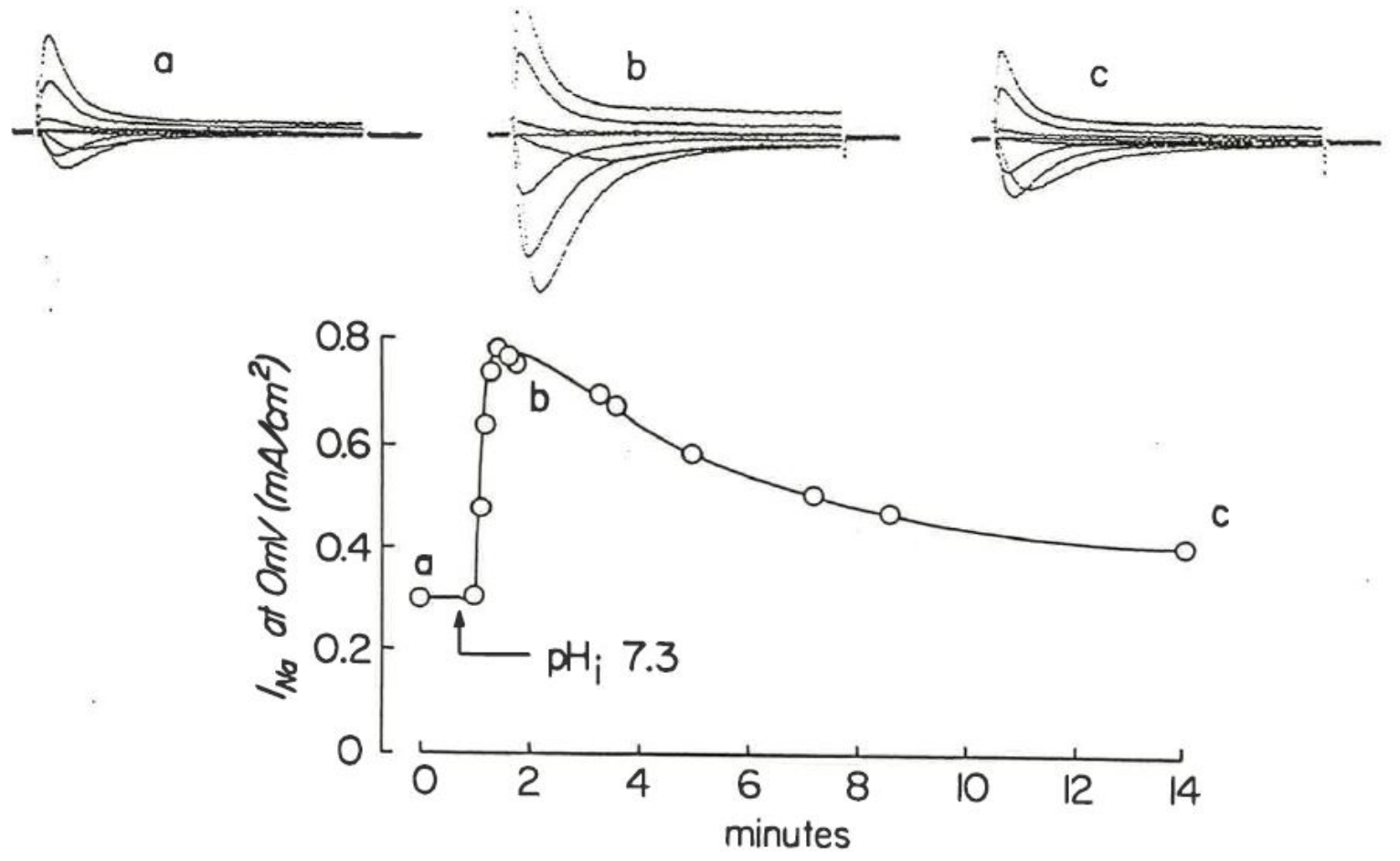
bioRxiv preprint doi: https://doi org/10.1101/2021.12.21.473550; this version posted December 22, 2021. The copyright holder for this preprint (which was not certified by peer review) is the author/funder, who has granted bioRxiv a license to display the preprint in perpetuity. It is made available under aCC-BY 4.0 International license.

Figure 10.

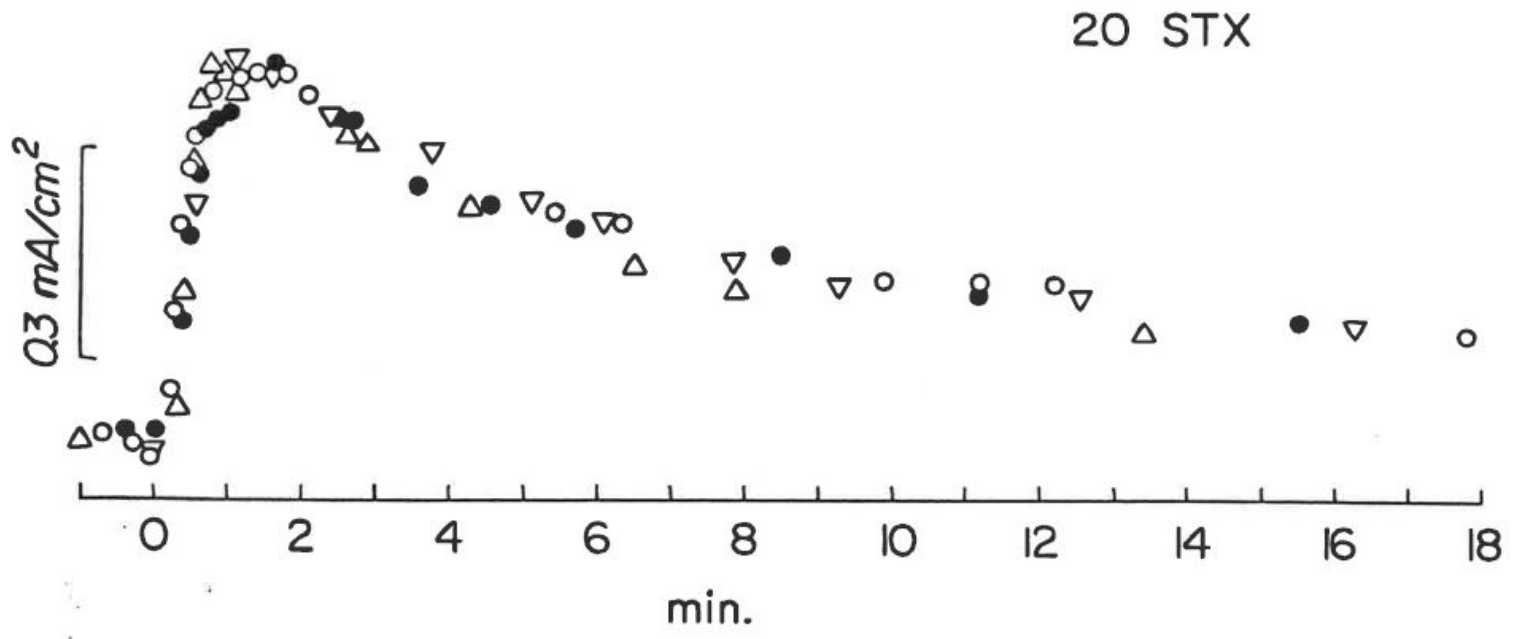


bioRxiv preprint doi: https://doi.org/10.1101/2021.12.21.473550; this version posted December 22, 2021. The copyright holder for this preprint (which was not certified by peer review) is the author/funder, who has granted bioRxiv a license to display the preprint in perpetuity. It is made available under aCC-BY 4.0 International license.

Figure 11.

A.

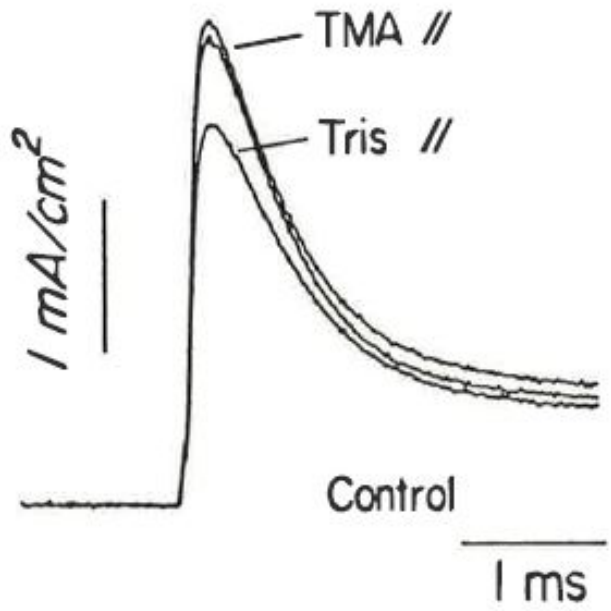

B.

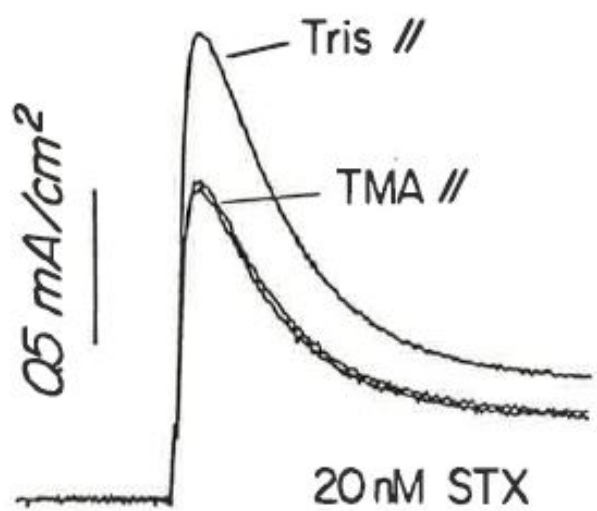

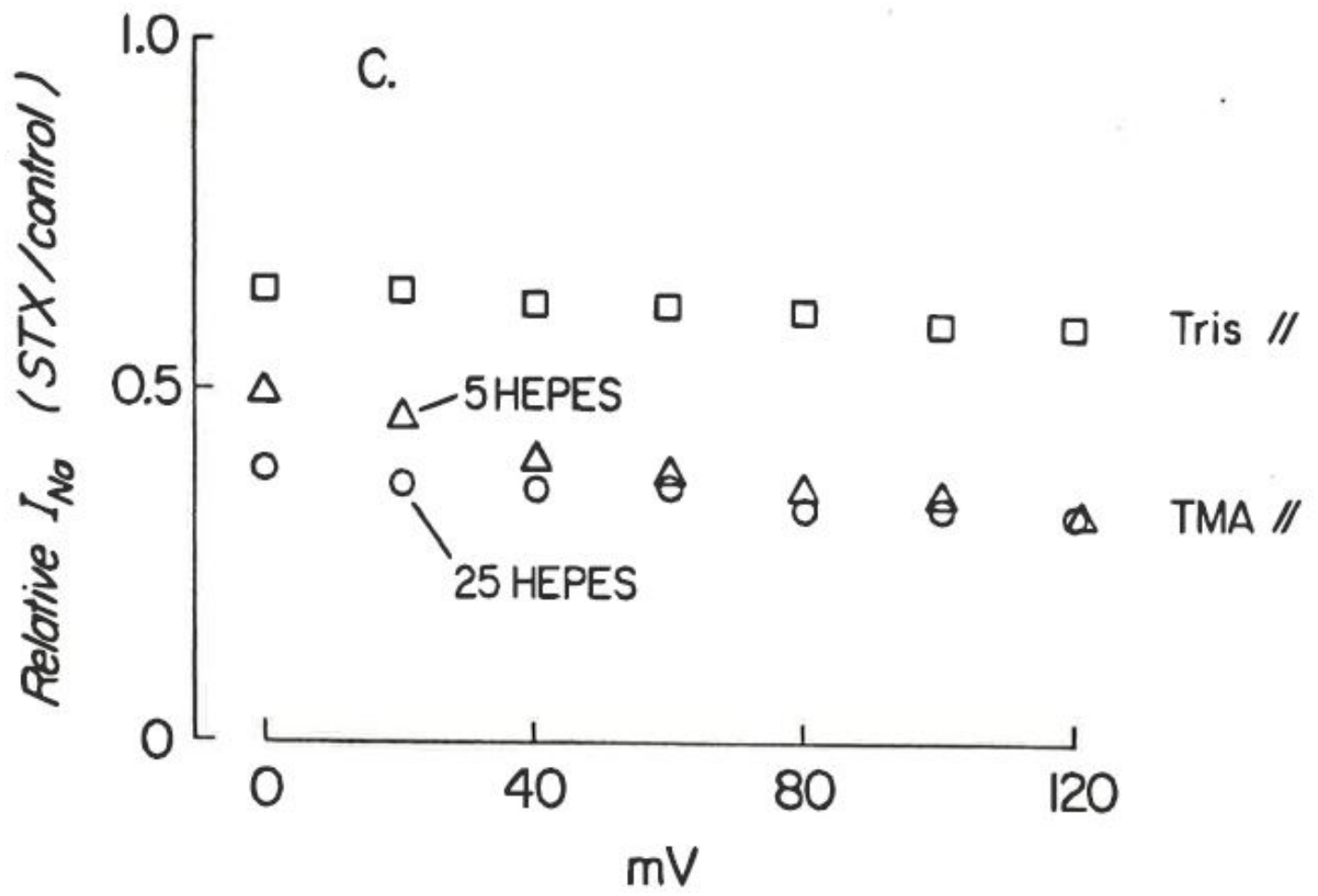

